\title{
Romaanin synty, kehitys ja kielioppi
}

\author{
Guido Mazzoni 20 I7: Theory of the Novel. Alkuteos Teoria del Romanzo (20I I). \\ Kääntänyt Zakiya Hanafi. Cambridge: Harvard University Press. 392 s.
}

Romaanin monipuoliset ja mukautuvat keinot tallentaa ja selittää ihmiskokemusta ovat tehneet sen historiasta menestyksekkään. I500-luvulla alkunsa saanut uusi kirjallisuuden laji, romaani, haastoi ja syrjäytti vuosituhannen loppuun mennessä eepos- ja draamakirjallisuuden. Romaanin menestys ei perustunut vain uusiin kirjallisiin innovaatioihin, kuten tavallisen ihmisen arkipäivän kuvaukseen ja kertojahahmon luomiseen, vaan yhtä lailla sen kykyyn omaksua sutjakkaasti muiden lajien keinoja. Romaani varasti ja lainasi erityisesti juuri epiikalta ja teatterilta mutta myös lyriikalta, kuvataiteelta, tiedotusvälineiltä ja elokuvalta.

Guido Mazzonin teos Theory of the Novel selittää, miten romaanista kasvoi dominoiva kaunokirjallisuuden muoto. Sen diakroninen lähestymistapa täydentää hienosti nykyaikana pääsääntöisesti synkronisesti ja narratologisesti painottuvia romaanin teoretisointeja, kuten David Hermanin teosparia Story Logic (2002) ja Basic Elements of Narrative (2009). Sen historiallinen käsittelytapa on sukua Mihail Bahtinin Kirjallisuuden ja estetiikan ongelmille (1979, Voprosy literatury i estetiki, 1975) ja Monika Fludernikin teokselle Towards a "Natural" Narratology (1996). Mazzonin teoksessa historiallisen kehityksen selitysvoima on vielä laaja-alaisempaa, ja romaanimuodon evoluutio ankkuroidaan tarkemmin aatteellisiin ja kulttuurihistoriallisiin ilmiöihin, kuten hegeliläisyyden nousuun ja laantumiseen sekä keskiluokan syntymiseen.

Analyysin suunta ja fokus ovat päinvastaiset kuin monessa nykyaikaisessa proosahistoriassa, joissa kirjallisen evoluution suurta kertomusta pyritään suhteellistamaan ja problematisoimaan. Mazzoni ei pyri löytämään kirjallisuuden historiasta aiemmin kartoittamattomia tekijöitä ja koulukuntia, eikä hän yritä analyysillaan horjuttaa kirjallisille periodeille hahmotettuja ajallisia kehyksiä. Päähuomio on romaanimuodon vuosisatoja kestävän kehityskaaren kuvaamisessa. Skaala on laaja: Theory of the Novel esittelee proosan muutosprosesseja laajoista mimeettisistä, temaattisista ja kerronnallisista kysymyksenasetteluista pienemmän mittakaavan, kuten kirjallisten motiivien, analyysiin asti.

Historiankirjoitus kuten taiteenalojen historiikitkin keskittyy herkästi vain uuden ja mullistavan kuvaamiseen. Moni proosahistoria esittelee kirjallisen evoluution sarjana avantgardistisia vallankumouksia tai taisteluna uudistavien ja taantumuksellisten voimien välillä. Uusien tekijöiden ja ilmaisutapojen läpimurtoja korostetaan dramaattisina tapahtumina, jopa katkoksina historiallisessa kehityksessä. Erityisesti kirjallisten koulukuntien vakiintuminen ja terminaalivaihe jäävät kuvaamatta. Tämä on erityisen tyypillistä 1900-luvun kirjallisia koulukuntia, kuten modernismia ja postmodernismia, kuvaaville analyyseille. 
Mazzoni ei sorru kirjallisuushistorian liialliseen dramatisointiin tai kertomuksellistamiseen. Proosan muodonmuutokset nähdään aina osana suurempaa kaavaa ja kehitystä. Teos valaisee tästä syystä poikkeuksellisen hyvin kirjallisuuden siirtymäkausia, kuten 1900-luvun kehitystä realismista modernismiin. Huomio ei kiinnity vain uuteen ja kirjallisuutta mullistavaan, vaan Mazzoni keskittää analyysiaan myös väistyvien ja hiipuvien ilmaisukeinojen kuvaukseen. Hän pystyy havainnollisesti erottamaan modernismin orastavat muodot jo 1800-luvun kirjallisuudessa, mutta yhtä lailla hän kiinnittää huomiota realistisessa kirjallisuudessa jäännöksenomaisesti vaikuttaviin melodraaman tyylipiirteisiin.

Romaanin synnyn ja varhaisvaiheiden (1500-1800) kehityksen kuvaus kulkee varsin vakiintuneita polkuja. Leijonanosa teoksesta pureutuu vuosien 1800-1940 välillä tapahtuviin muutoksiin ja mullistuksiin romaanin keinovalikoimassa. Vakiintuneen, mutta ongelmallisen realismi/modernismi-kahtiajaon sijasta Mazzoni tarkastelee 1800-1940lukujen kirjallisuutta kolmen vaiheen kautta. I800-luvun ensimmäisinä vuosikymmeninä romaani vakiinnuttaa keskeisen kielioppinsa (kertojan välittämä kuva aikaan ja paikkaan sidotuista henkilöhahmoista, joiden elämää kuvataan näytelmän tavoin avainkohtauksiin keskittyen).Vuoden I850 tienoilta alkaa vähittäinen ja vuosisadan loppua kohden kiihtyvä kehitys kohti modernismia: staattisista ja eeposmaisista kerronta-asetelmista sekä melodramaattisista ja teatraalisista juoni- ja ihmiskäsityksistä siirrytään kohti modernistisen romaanin repertuaaria. Aika- ja juonikäsitykset sirpaloituvat ja monipuolistuvat, tavallisen ihmisen arkisen ja käännekohdattoman kokemuksen kuvaus nousee yhä keskeisemmäksi aiheeksi, kertojahahmo(je)n epistemologinen suvereniteetti murtuu ja sisäisen fokalisaation muodot yleistyvät. 1900-luvun alussa nämä radikaalit muutokset viedään ääripisteeseensä ja ne alkavat vakiintua romaanin yleisiksi keinoiksi. Proosan modernisoitumisessa on kuitenkin kyse hitaasta ja pitkästä kehityskulusta, ei radikaaleista ja äkillisistä vallankumouksista, toisin kuin moni modernismitutkimus, kuten Jesse Matzin The Modern Novel (2004) ja Stephen Kernin The Modernist Novel (20I I), asian esittää.

Sen sijaan modernismin jälkeistä kirjallisuutta käsitellään pintapuolisesti ja penseästi. Mazzoni näkee 1930-1950-luvun aikana, jona romaani ei ensimmäistä kertaa historiassaan uudistu vaan sen kehitys pysähtyy, jopa taantuu. 1960-luvun Mazzoni nimeää avantgarden toiseksi aalloksi. Sen ero 1900-luvun ensimmäiseen avantgardeen on kuitenkin se, etteivät sen poeettiset innovaatiot vakiinnu toisin kuin 1900-luvun alun kirjailijoiden kehittelemät keinot.

Mazzoni pelaa tutkimuksessaan yksinkertaisella ja yleiskielisellä käsitteistöllä. Teoksensa johdanto-osuudessa hän perehtyy laajemmin vain kahteen käsitteeseen. Hän syventyy kirjallisuuden tuhatvuotiseen keskusteluun mimesiksestä eli sen kyvystä jäljitellä todellisuutta. Lisäksi hän esittelee oman kertomuskäsityksensä, joka on yhdistelmä klassista strukturalismia ja retorista ja kognitiivista narratologiaa. Mazzonin mukaan kertomuksessa on tiivistäen kyse kerronnan ja diskurssien keinoin luodusta ontologisesta piiristä, joka on kansoitettu toisiinsa sidoksissa 
olevilla ja toisistaan erottautuvilla ihmisillä, jotka on sijoitettu tiettyyn aikaan ja paikkaan ja joita ajavat erilaiset halut ja päämäärät.

Theory of the Novel ei vaadi lukijaltaan laajaa kulttuurihistoriallista pohjatietoa tai syvää kirjallisuudentutkimuksen kielen hallintaa. Mazzoni kirjoittaa ilmaisuvoimaisesti, havainnollisesti ja selkeästi, ja hänen argumentaatiotaan on helppo seurata. Se ei tee teoksesta kuitenkaan populaaria yleisesitystä, vaan teos on selvästi suunnattu lukijalle, joka tuntee vähintään kursorisesti kirjallisuuden historian ja eri periodin ominaispiirteet.

Mazzoni hyödyntää kunkin aikakauden omia tekstejä ja teorioita usealta eri kielialueelta. Erityisesti lähteiden ja esimerkkien käyttö - ei vain proosa- ja tutkimuskatkelmien, vaan myös filosofisten tekstien, kirjakritiikkien ja esseiden - on ihailtavaa ja monipuolista. Fokus on laajempi kuin monessa muussa kirjallisuudenhistoriassa, jotka kuvaavat lähinnä vain kirjallisissa keskuksissa, kuten Pariisissa ja Lontoossa, tapahtuvia innovaatioita. Tutkimus liikkuu kiitettävän laajasti eurooppalaisessa ja amerikkalaisessa kehyksessä, mutta länsimaiden ulkopuolelle, Aasiaan ja Afrikkaan, Mazzoni ei juuri käännä valokeilaansa. Yleiseurooppalaisuus tekee teoksesta "monikielisen". Se asettaa muuten yleiskielisen teoksen lukijalle joskus haasteita: laaja ja todistusvoimainen esimerkkiaineisto kuljettaa lukijan kunkin kirjallisen ilmiön alkulähteille, mutta joskus lukijan on hankala palauttaa mieleen teoksen runsaasti käyttämiä latinan-, italian-, ranskan-, venäjän- ja saksankielisiä avaintermejä ja -käsitteitä.

Kehuin edellä Mazzonin ennakkoluulotonta ja yleistävää tapaa palauttaa romaanin repertuaarissa tapahtuvia muutoksia laajojen kulttuurillisten ilmiöiden alle. Teksti etenee 3-6 kohdan jaotteluin, joissa eri epookkeina toteutuvat muutokset esitetään luettelonomaisina listauksina. Ajoittain, etenkin modernismia käsittelevässä jaksossa, numerointi ja listaaminen tekevät käsittelystä turhan skemaattista ja yleisellä tasolla liikkuvaa. Mazzoni palauttaa esimerkiksi modernismin hyvin kategorisesti kolmeen keskeiseen käännekohtaan (turning point): sisäänpäin kääntyvään kerrontaan (inward turn), esseistisyyteen (essay turn) ja vieraannuttamiseen (estrangement). Tämä ei estä Mazzonia myöhemmin jaottelemasta vielä erikseen modernistisen siirtymävaiheen vaikutuksia todellisuuskuvaan (viiden kohdan lista), kertojaan (kahden kohdan lista), juoneen (ei listausta) ja henkilöhahmoihin (neljän kohdan lista). Ajoittain on vaikea muistaa, eritteleekö jaottelu kerronnassa, henkilöhahmoissa vai rakenteessa tapahtuvissa muutoksia.

Ansiokkaalla makrotason analyysillä on toinenkin varjopuoli. Erityisesti 1900-lukua käsittelevän jakson aikana analyysi keskittyy myös liiaksi laajoihin ihmis- ja maailmankuvassa tapahtuviin ja romaanin kehitykseen heijastuviin paradigmanmuutoksiin, kuten muuttuviin moraalikäsityksiin ja proosan psykologisoitumiseen. Mazzoni ei näin ollen tule pohtineeksi juuri lainkaan miten modernisaatio ja muutokset arkisessa elämässä siirtyvät kirjallisuuteen. Esimerkiksi kaupungistuminen, teknologian kehitys, sotien vaikutus, kapitalismi, populaarikulttuuri, globalisoituminen ja muutokset sukupuolirooleissa ovat ilmiöitä, joiden vaikutusta romaaniin Mazzoni tarkastelee yllättävän niukasti. 
Kokonaisuudessaan Theory of the Novel on vahva ja innostava esitys romaanimuodon synnystä, kehityksestä ja kieliopista. Se on sekoitus kirjallisuudentutkimusta ja kulttuurihistoriaa, mikä ei lainkaan heikennä sen kirjallisuustieteellistä arvoa. Koska kyky ilmaisutavan ja todellisuuskäsityksen radikaaleihin muodonmuutoksiin on koodattu proosakirjallisuuden luonteeseen, kertomuksen muotojen diakroninen tarkastelu on erottamaton osa myös kulttuurihistoriaa. Kertomusmuoto heijastelee aina myös laajoja yhteiskunnallisia, tieteellisiä ja kulttuurillisia paradigmamuutoksia.Vaikka romaani käy läpi merkittäviä metamorfooseja ja vaikka Roland Barthesin sanoin "maailmassa on laskematon määrä erilaisia kertomuksen muotoja”, Mazzoni onnistuu teoksessaan koskettamaan ja määrittelemään proosakerronnan muuttumatonta ontologista ydintä ja merkitystä ihmisille ja kulttuurille.

\section{Kirjoittaja}

Matias Koriseva, FM, tohtorikoulutettava, kotimainen kirjallisuus, Helsingin yliopisto, matias.koriseva@helsinki.fi 
